\title{
Tools Used by Countries to Counteract Aggressive Tax Planning in Light of Transparency
}

\author{
Irma Mosquera Valderrama**, Addy Mazz***, Luís Eduardo Schoueri*****, Natalia Quiñones******, Craig \\ West $* * * * * *$, Pasquale Pistone $* * * * * * * *$ \& Frederik Zimmer**********
}

\begin{abstract}
The aim of this article is twofold. The first aim is to provide a comparative overview of the domestic anti-avoidance rules with specific reference to Brazil, Colombia, South Africa and Uruguay to evaluate the application of these rules to tackle aggressive tax planning. The second aim is to assess whether or not the application of general anti-avoidance rules (GAARs) in these countries is consistent and clear (transparent) for the taxpayer. The main argument is that to tackle aggressive tax planning, countries should have GAARs in accordance with the standard of fiscal transparency as developed in this article (i.e. availability, clarity, simplicity and reliability). Furthermore, the relationship between the taxpayer and tax administration should be enhanced considering mutual trust, legitimate expectations and respect for the taxpayers' rights. This article provides recommendations to enhance the relationship between tax administration and taxpayers to facilitate a coordinated relationship. Such a coordinated relationship means, on the one hand, that the governments (tax administrations) are provided access to the information regarding the activities of the taxpayer; and, on the other hand, that taxpayers voluntarily disclose the structure and nature of the economic activities or businesses in the country.
\end{abstract}

\section{INTRODUCTION}

The aim of this article is twofold. The first aim is to provide a comparative overview of the domestic antiavoidance rules with specific reference to Brazil,
Colombia, South Africa and Uruguay to evaluate the application of these rules to tackle aggressive tax planning (ATP). ${ }^{1}$ The second aim is to assess whether or not the application of general anti-avoidance rules

\section{Notes}

This article form part of the comparative research conducted in terms of the DeSTaT Research Project (Sustainable Tax Governance in Developing Countries through Global Tax Transparency). In terms of this project the 'South Antennae' (Brazil, Colombia, South Africa and Uruguay) provided reports based on questionnaires drafted by the 'North Research Units' (Norway and Austria). The Heads of the North Antennas include Frederik Zimmer (Norway) and Pasquale Pistone (Austria). The Heads of the South Antennas include Addy Mazz (Uruguay), Natalia Quiñones (Colombia), Luís Eduardo Schoueri (Brazil), Jennifer Roeleveld (South Africa). The choice for these countries as South Antennae has been addressed in the DeSTaT Grant Application. In a nutshell, Brazil, Colombia and Uruguay represent three different countries within the same region: Brazil as one of the advanced economies in the region with a complex tax system, Colombia a country with the desire to cooperate but with limited resources, and Uruguay as one of the countries that have been striving to comply with the OECD standards. South Africa represents one of the most advanced economies in the region, with a fairly sophisticated tax framework and extensive tax treaty network.

Questionnaires on topics agreed by all institutions party to the project are drafted (primarily by the North Research Units Norway) and submitted to the South Antennae. Questionnaires are addressed through local seminars which aim at engaging all potential relevant stakeholders. Questionnaires encompass a legal-descriptive function as well as a more policy-oriented dimension. The questionnaires intend to highlight convergences and divergences between the selected pools of jurisdictions. Convergences and divergences are monitored in relation to both specific challenges/needs and to potential solutions. Questionnaires have incorporated survey sections, aimed at providing an accurate representation of the current state of affairs together with more policy-oriented sections. Funding for the Project is provided by the Research Council of Norway. Further information about the Project can be retrieved on the following website: http://www.jus.uio.no/ior/english/research/projects/global-tax-tranparency/.

** PhD University of Groningen. Senior Research Associate at the International Bureau of Fiscal Documentation, and Tax Adviser Hamelink \& Van den Tooren. Special acknowledgment to Professor I.J.J. Burgers of the University of Groningen, the Netherlands. Email: irma.mosquera@gmail.com. Internal (scientific) reviewer for comments on an earlier version of this article.

*** Professor of Public Finance Law, Universidad de la República, Montevideo, Uruguay.

***** Professor of Tax Law, Universidade de São Paulo, São Paulo, Brazil.

****** Researcher at the Colombian Tax Institute.

******* Associate Professor of Tax, University of Cape Town, Cape Town, South Africa and Managing Editor World Tax Journal at the International Bureau of Fiscal Documentation.

**:****** Academic Chairman of the International Bureau of Fiscal Documentation, Jean Monnet ad Personam Chair of European Tax Law and Policy at the Institute for Austrian and International Tax Law (WU, Vienna, Austria) and Professor of Tax Law, University of Salerno, Italy.

Emeritus Professor of Tax Law, University of Oslo, Norway.

See supra $\mathrm{n} .1$ for the reasoning to choose these countries.

In a nutshell, Brazil, Colombia and Uruguay represent three different countries within the sameregion: Brazil as one of the advanced economies in the region with a complex tax system, Colombia a country with the desire to cooperate but with limited resources, and Uruguay as one of the countries that have been striving to comply with the OECD standards. South Africa represents one of the most advanced economies in the region, with a fairly sophisticated tax framework and extensive tax treaty network 
(GAARs) in these countries is consistent and clear (transparent) for the taxpayer. This article considers the GAAR and not specific anti-avoidance rules (SAAR), which aim to target specific transactions that have already been identified as unacceptable tax avoidance or ATP. ${ }^{2}$

With the aim of protecting a country's tax base from erosion, countries have introduced in their domestic law (i.e. statutory law and/or case law) and in their tax treaties, rules to tackle tax abuse, unacceptable tax avoidance and ATP. ${ }^{3}$ However, countries have not been successful in countering base erosion and ATP where multinationals have made use of mismatches between domestic and international legal rules and there is a lack of a co-ordinated international approach to base erosion and profit shifting (BEPS). According to the Organization for Economic Cooperation and Development (OECD), multinational enterprises have been able to significantly minimize their tax burden through exploitation of tax arbitrage opportunities and utilization of structures testing the boundaries of what countries may consider as acceptable tax planning. The result has been that multinationals have become more confident in taking aggressive tax positions. ${ }^{4}$

In response, the OECD, following the political mandate of the G-20, ${ }^{5}$ launched in 2013 the BEPS Project and its Action Plan. ${ }^{6}$ The OECD in the BEPS Action Plan called for 'fundamental changes to the current mechanisms and the adoption of new consensus-based approaches, including anti-abuse provisions, designed to prevent and counter base erosion and profit shifting' ${ }^{7}$

The BEPS Action Plan introduced 15 Actions partly addressing ATP. ${ }^{8}$ From these 15 Actions, the OECD identified Actions 5, 6, 13 and 14 as minimum standards to be implemented by countries participating in the BEPS Inclusive Framework. ${ }^{9}$ The other Actions (1-4, 7-9, and 10-12) are considered best practices and recommendations for countries to implement. In addition, Action 15 provides for a multilateral convention to implement tax treaty related measures to prevent BEPS in the existing network of bilateral tax treaties. At the time of writing (August 2017), more than seventy countries have signed the multilateral convention. ${ }^{10}$ From the countries of research, all countries are participating in the BEPS Inclusive Framework and all countries except Brazil have signed the multilateral convention. ${ }^{11}$

This article provides, firstly, a comparative overview of the status quo of the GAARs in the countries of research before implementation of BEPS. At this stage, it is too early $^{12}$ to analyse the implementation of BEPS Actions, including the BEPS minimum standards, in the selected countries. $^{13}$

Following the comparative overview of GAARs in the countries of research, this article secondly assesses whether the application of GAARs is consistent and clear (transparent) for the taxpayer. This article argues that to keep the balance between the need for jurisdictions to enforce their tax rules and the taxpayer's right to have certainty in

\section{Notes}

Examples of specific anti-avoidance rules are thin capitalization rules to limit interest deductions.

Examples of these rules in tax treaties are the beneficial ownership, the limitation on benefits test, the main purpose test, the subject to tax clause and the switch over clause amongst others. At domestic level, countries have introduced GAARs referencing substance over form, business purpose, and abuse of law.

4 OECD, Action Plan on Base Erosion and Profit Shifting 7-8 (OECD Publishing 2013), http://dx.doi.org/10.1787/9789264202719-en (accessed 31 Aug. 2017).

5 The BEPS and the Action Plan have been endorsed in the G20 meetings at Mexico (June 2012) and St Petersburg (Sept. 2013) respectively. In the G20 meeting in St Petersburg (Sept. 2013), G20 leaders committed to address base erosion and profit shifting, tackling tax avoidance and promoting transparency and automatic exchange of information. See in particular, para. 50 of the Declaration, where it has been stated that: 'In a context of severe fiscal consolidation and social hardship, in many countries ensuring that all taxpayers pay their fair share of taxes is more than ever a priority. Tax avoidance, harmful practices and aggressive tax planning have to be tackled.' http:// www.g20.utoronto.ca/2013/2013-0906-declaration.html (accessed 31 Aug. 2017).

6 OECD, Addressing Base Erosion and Profit Shifting (OECD Publishing 2013), http://dx.doi.org/10.1787/9789264192744-en (accessed 31 Aug. 2017) and OECD, supra n. 4. OECD, supra n. 4, at 13 .

8 The Actions considering base erosion and aggressive tax planning are: Action 2 on Hybrid Mismatches, Action 3 on Controlled Foreign Corporation Rules, Action 4 on base erosion through interest and other financing expenses, Action 5 on Harmful Tax Regimes, Action 6 on Tax Treaty Abuse, Action 8 to 11 on transfer pricing and Action 12 requiring taxpayers to disclose their aggressive tax planning arrangements. Other Actions are Action 1 on the Digital Economy, Action 7 on the definition of a permanent establishment, Action 13 on transfer pricing documentation and, Action 14 addressing the mutual agreement procedure.

9 The BEPS Actions have been adopted by the BEPS 44 Group: OECD, OECD Accession countries and G20. At the Kyoto meeting in June 2016, other countries were invited to participate in BEPS as BEPS Associates. These countries are now part of the so-called 'BEPS Inclusive Framework' and are required to implement the 4 BEPS Actions identified as minimum standards. At the time of writing (Aug. 2017), more than hundred countries had committed to this BEPS Inclusive Framework. Information available at http://www.oecd.org/tax/beps/inclusive-framework-on-beps-composition.pdf (accessed 31 Aug. 2017).

10 See for a list of the countries http://www.oecd.org/tax/treaties/beps-mli-signatories-and-parties.pdf (accessed 31 Aug. 2017).

11 For the countries that have not signed the multilateral convention but who are participant of the BEPS inclusive framework (e.g. Brazil), the possibility exists to adopt the minimum standard (e.g. Action 6) by means of bilateral negotiations. See para. 16 Explanatory Statement to the Multilateral Convention. https://www.oecd.org/tax/treaties/ explanatory-statement-multilateral-convention-to-implement-tax-treaty-related-measures-to-prevent-BEPS.pdf (accessed 31 Aug. 2017).

12 Therefore, a forthcoming (2019) article in the framework of the DeSTaT project will analyse whether, due to BEPS Actions, new rules have been introduced in the countries to deal with abusive, aggressive and harmful tax practices and if so whether these rules follow the content of the BEPS Actions. The implementation of BEPS has been the object of the Seminar 1 at the International Fiscal Association. See S. Shay \& A. Christians, General Report, BEPS and Taking Stock. Which Focused on the Assessment of BEPS: Origins, Standards, and Responses vol. 102a (IFA Cahiers, Online Books IBFD 2017).

13 The main reason is that (as of Aug. 2017) the review on the implementation of the BEPS Minimum Standards i.e. Actions 5, 6, 13, and 14 by the countries participating in the BEPS Inclusive Framework have not yet taken place. The OECD has published the peer review documents including the terms of reference and methodology for peer reviews all for the BEPS minimum standards. The OECD has also announced that the first standard that will be reviewed and monitored will be Action 14 . See http://www. oecd.org/tax/beps/beps-action-14-peer-review-and-monitoring.htm (accessed 31 Aug. 2017). 
the tax rules applicable to their business activities, transparency should be evaluated based on the availability, clarity, simplicity and reliability of the anti-avoidance rules. In this framework, the notion of transparency has a broader meaning than the meaning articulated by the OECD regarding exchange of information. ${ }^{14}$

The broader approach to transparency has also been addressed by several scholars. For Owens, the notion of transparency should include clarity, simplicity and reliability. ${ }^{15}$ Furthermore, Owens states that 'greater transparency between the taxpayer and the tax authorities is a good thing as it will lead to fewer disputes, greater mutual understanding and a relationship based on cooperative compliance'. ${ }^{16}$ Ring addresses two notions being transparency and disclosure. Ring states that transparency includes the understanding by the tax administration of the taxpayer's activities and that disclosure requires the need for a country to have access to the information necessary to provide transparency regarding the taxpayer's activities'. ${ }^{17}$ Following this broad approach, in this article it is argued that fiscal transparency requires the drafting of tax rules that are clear for the tax administration to enforce and on which the taxpayer may rely. As rightly pointed out by Schoueri and Barbosa the notion of transparency 'should be extended to the state itself and to covering the tax system as a whole'. ${ }^{18}$

The main argument of this article is that to tackle ATP, countries should have GAARs in accordance with the standard of fiscal transparency as developed in this article (i.e. availability, clarity, simplicity and reliability). Furthermore, the relationship between the taxpayer and tax administration should be enhanced considering mutual trust, legitimate expectations and respect for the taxpayers' rights.

Following the argument for an enhanced relationship between taxpayers and tax authorities, this article, finally, provides recommendations to enhance the relationship between tax administration and taxpayers to facilitate a coordinated instead of an adversarial position. Such a coordinated relationship means, on the one hand, that the governments (tax administrations) are provided access to the information regarding the activities of the taxpayer; and, on the other hand, that taxpayers voluntarily disclose the structure and nature of the economic activities or businesses in the country.

This article is structured as follows: section 2 introduces tax avoidance and ATP. Section 3 provides the comparative analysis of the anti-avoidance rules in the surveyed countries. Section 4 addresses the use of exchange of information to tackle ATP in the surveyed countries. Section 5 addresses the enhanced relationship between taxpayer and tax administration in the surveyed countries. Section 6 concludes as to whether the measures taken by the surveyed countries are consistent with the standard of fiscal transparency including availability, clarity, simplicity and reliability of the anti-avoidance rules and the development of enhanced relationships between the tax administrations and taxpayers and provides recommendations.

\section{TaX aVoidance AND Aggressive taX PLANNING}

\section{I Tax Avoidance}

Countries appear to have a common understanding of the distinction between tax evasion and tax avoidance. ${ }^{19}$ International organizations (IOs) such as the OECD state that 'tax evasion' is a term that is difficult to define but which is generally used to mean illegal arrangements where liability to tax is hidden or ignored, i.e. the taxpayer pays less tax than he is legally obligated to pay by hiding income or information from the tax authorities. Tax avoidance has been defined by the OECD stating that it is 'a term that is difficult to define but which is generally used to describe the arrangement of a taxpayer's affairs that is intended to reduce his tax liability and that although the arrangement could be strictly legal it is usually in contradiction with the intent of the law it purports to follow'. ${ }^{20}$ However, the distinction between 'acceptable tax avoidance' and 'unacceptable tax avoidance'

\section{Notes}

14 A standard of transparency and exchange of information has been developed by the Organization for Economic Cooperation and Development (OECD) in its 2010 Tax Treaty Model and in the 2002 Model Agreement on Exchange of Information in Tax Matters. This standard requires exchange of 'foreseeable relevant' information, respect for taxpayers' rights including right to confidentiality, removal of bank secrecy, the availability of reliable information, and the powers by the country (tax administration) to obtain such information. Global Forum Terms of Reference (Nov. 2013). Background Brief. Annex I, at 6, http://www.oecd.org/tax/transparency/global_forum_background \%20brief.pdf (accessed 31 Aug. 2017).

15 J. Owens, Moving Towards Better Transparency and Exchange of Information on Tax Matters, Vol. 63 (11) Bull. Int'l Tax'n 557 (2009).

16 J. Owens, International Tax Transparency: The 'Full Monty', Vol. 68 (9) Bull. Int'l Tax'n 384 (2014). The topic of co-operative compliance will be dealt with in other articles in the framework of the DeSTaT project.

17 D. Ring, Transparency and Disclosure, Selected Topics in Protecting the Tax Base in Developing Countries (United Nations Sept. 2014), Retrievable at the following link: http://www.un.org/esa/ffd/tax/2014TBP2/Paper_TransparencyDisclosure.pdf (accessed 31 Aug. 2017).

18 For Schoueri and Barbosa transparency 'should be used as mechanism for the creation of a mature relationship between state and citizen, and the result is that taxpayers feel part of the community and therefore involved in the process of granting states the means for their activities'. L. E. Schoueri \& M. C. Barbosa, Transparency: From Tax Secrecy to the Simplicity and Reliability of the Tax System, 5 Brit. Tax Rev. 677-678 (2013).

19 For a definition of tax evasion and tax avoidance and their boundaries see V. Uckmar, General Report, Tax Avoidance and Tax Evasion vol. 68a, 20-23 (IFA Cahiers, Online Books IBFD 1983).

20 OECD, Glossary of Terms, http://www.oecd.org/ctp/glossaryoftaxterms.htm (accessed 31 Aug. 2017). 
is far less clear. As rightly argued by Arnold and Wilson, "the problem is drawing a line between "acceptable" tax avoidance and "unacceptable" tax avoidance - to balance taxpayers' need for a reasonable degree of certainty and predictability in planning their affairs and the government's need to protect its tax base'. ${ }^{21}$

In general, the approach towards the boundaries between accepted (legally effective) and unaccepted tax avoidance (obtaining benefits not intended by the legislator and legally ineffective due to the use of anti-avoidance doctrines) is followed by countries around the world. ${ }^{22}$ Tax scholars have also addressed the distinction between acceptable and unacceptable tax avoidance. For instance, Thuronyi classifies this as tax minimization and tax avoidance, but with the same features that correspond to acceptable tax avoidance and unacceptable tax avoidance. For Thuronyi, tax minimization (acceptable tax avoidance) is a 'behaviour that is legally effective in reducing tax liability'. Tax avoidance for Thuronyi (being unacceptable tax avoidance) has the same aim (i.e. reduction of tax liability) but 'that is found to be legally ineffective (perhaps because of an anti-abuse doctrine or by construction of the tax law) although it does not constitute a criminal offense'. ${ }^{23}$

While there may be consensus as to the broad conceptualization of tax evasion, acceptable tax avoidance and unacceptable tax avoidance, there are differences in the rules used by countries to tackle tax avoidance. In the 2002 International Fiscal Association (IFA) report, the general reporter classified the rules on tax avoidance articulated in the national reports into three categories: (1) neither statute-based nor court based general measures; (2) a statute-based general tax avoidance rule; and (3) court-based general tax avoidance rule(s). ${ }^{24}$ From the analysis of the twenty-seven national reports at that time (2002), the general reporter concluded that there is a significant trend in the direction of more statute-based rules coming into effect'. ${ }^{25}$
Similarly, in the 2010 IFA report, ${ }^{26}$ forty-four national reports provided an overview of the anti-avoidance doctrines and provisions with an international scope. From the analysis, the general reporter stated that 'the branch reports establish that most countries have either statutory or court developed anti-avoidance rules. The nature and scope of these rules differ considerably from country to country. The doctrines can be summarised as sham, legally ineffective transactions, substance over form, abuse of law, fraus legis, or simply as the general anti-avoidance rule (GAAR)'. ${ }^{27}$ The differences in approach to the nature and scope of these rules is also demonstrated in the comparative overview of the GAARs in the surveyed countries (see section 3 below).

\subsection{Aggressive Tax Planning}

In the last decade, IOs such as the OECD and nongovernmental organizations (NGOs) ${ }^{28}$ have referred to 'aggressive tax planning', a phrase without a legal definition, to introduce the concept of 'fair share of taxes' when considering tax structures employed by multinational enterprises (in the main) and perhaps expanding the consensus of 'unacceptable tax avoidance'. ${ }^{29}$ The OECD has stated that tax avoidance is 'a term that is difficult to define but which is generally used to describe the arrangement of a taxpayer's affairs that is intended to reduce his tax liability and that although the arrangement could be strictly legal it is usually in contradiction with the intent of the law it purports to follow'. ${ }^{30}$

Furthermore, in 2008, the OECD published a Study into the Role of Tax Intermediaries and their engagement in ATP. ${ }^{31}$ In this Study, the OECD referred to ATP without providing a specific or clear definition. However, the Glossary stated that ATP refers to (1) planning involving a tax position that is tenable but has unintended and unexpected tax revenue consequences and (2) taking a tax position that is favourable to the

\section{Notes}

21 B. Arnold \& J. Wilson, Aggressive International Tax Planning by Multinational Corporations: The Canadian Context and Possible Responses (2 Oct. 2014). SPP Research Paper No. 07.29 at 16. Available at SSRN: https://ssrn.com/abstract=2510950 (accessed 31 Aug. 2017).

22 For an overview of tax avoidance in twenty-two countries see F. Zimmer, General Report, Form and Substance in Tax Law vol. 87a, 37-50 (IFA Cahiers, Online Books IBFD 2002).

23 V. Thuronyi et al., Comparative Tax Law Ch. 5 (2d ed., Kluwer Law International 2016).

24 F. Zimmer, supra n. 22, at 37-38.

25 Ibid., at 38. The GAARs will be discussed in the 2018 IFA Seoul Congress. Subject 1 which deals with Anti-avoidance measures of general nature and scope. GAAR and other rules.

26 See S. van Weeghel, General Report, Tax Treaties and Tax Avoidance: Application of Anti-Avoidance Provisions vol. 95a (IFA Cahiers, Online Books IBFD 2010).

27 Ibid., at 22 .

28 Gribnau has further elaborated the concept of fairness stating that the discussion of NGO's has also brought a new dimension to the concept of fairness mainly calling for taxpayers to pay fair share taxes not only as required by law, but also as expected from society. See Hans Gribnau \& Ave-Geidi Jallai, Good Tax Governance: A Matter of Moral Responsibility and Transparency, Vol. 1 (1) Nordic Tax J. 70-88 (12 May 2017). Available at SSRN: https://ssrn.com/abstract=3021914 (accessed 31 Aug. 2017).

29 For a discussion of the use of fairness by IOs, NGOs, SOs and governments in respect of developing countries. See I. Burgers \& I. Mosquera, Corporate Taxation and BEPS: A Fair Slice for Developing Countries?, (8) Erasmus L. Rev. 29-47 (2017). DOI: 10.5553/ELR.000077 (accessed 31 Aug. 2017).

30 OECD, supra n. 20 .

31 Tax intermediaries is a collective term used by the OECD for tax advisers and financial institutions. See OECD, Study into the Role of Tax Intermediaries (2008). Glossary at 88, http://www.oecd.org/tax/administration/studyintotheroleoftaxintermediaries.htm\#table (accessed 31 Aug. 2017). 
taxpayer without openly disclosing that there is uncertainty whether significant matters in the tax return accord with the law. The Study furthers elaborates that the first situation may result in 'tax legislation being misused to achieve results which were not foreseen by the legislators'. The second situation addresses the concern of revenue bodies 'to the risk that taxpayers will not disclose their view on the uncertainty or risk taking in relation to grey areas of law (sometimes, revenue bodies would not even agree that the law is in doubt)'. ${ }^{32}$

The term ATP without a clear definition has been also used by the OECD in the BEPS Action Plan when referring to tax practices resulting in BEPS by multinationals. ${ }^{33}$ In the BEPS Action Plan, the OECD stated that ATP has reduced the tax burden of multinationals leading 'to a tense situation in which citizens have become more sensitive to tax fairness issues'. ${ }^{34}$ NGOs such as Tax Justice Network stated in 2014:

in a highly globalised world dominated by large multinational corporations, it is essential to ensure that taxes are paid where the true economic activity occurs. Under current global rules, this is often not the case, and companies are able to shift profits around the globe to places where they will be taxed less. This has a particularly devastating impact on developing countries. ${ }^{35}$

Finally, tax schemes used by companies in general and by high net worth individuals have been also addressed as ATP mainly by countries and NGOs. ${ }^{36}$

Unlike the OECD, the European Union has defined ATP in the European Commission Recommendation of 6 December 2012 on ATP C (2012) 8806 Final (the '2012 Recommendation'). The European Commission stated in the 2012 Recommendation that aggressive tax planning consists in taking advantage of the technicalities of a tax system or of mismatches between two or more tax systems for the purpose of reducing tax liability. ${ }^{37}$ However, this definition has been only provided by the EU in a non-binding (recommendation) instrument, therefore EU countries are not required to introduce this definition into their domestic law. Certainly, non-EU countries (third countries) are not bound by this EU definition.

The 2016 Tax Avoidance Package, including the AntiAvoidance Directive (ATAD 1), made reference to the 2012 Recommendation definition of ATP, but fell short of endorsing it. The Tax Avoidance package provides for 'concrete measures to prevent aggressive tax planning, to boost transparency and create a level playing field for all business in the EU, ${ }^{38}$ Neither the text of ATAD 1 (for EU countries) nor the text of ATAD 2 (for third (non-EU) countries) contain a definition of ATP resulting in a potential lack of coherence or inconsistency on introduction of the ATAD 1 and ATAD 2 by EU countries into their domestic legislation i.e. by 31 December 2018 and by 1 January 2020 ATAD $2 .{ }^{39}$

The boundaries between ATP and tax abuse have also been addressed by some tax scholars. For instance, Pistone argues that ATP is a new conceptual category of global tax law. It consists in the exploitation of crossborder disparities across tax systems with a view to achieving tax advantages that States would otherwise not have meant to give. Therefore, ATP should be differentiated from tax abuse and tax avoidance. ${ }^{40}$ As rightly stated by Pistone abusive tax avoidance reflects purely artificial transactions lacking valid economic substance whereas ATP is not abusive, rather it is the result of the misalignment between taxing powers and value creation. ${ }^{41}$

\section{Notes}

32 Ibid., at 87.

33 In the BEPS Action Plan, the OECD stated that aggressive tax planning has reduced the tax burden of multinationals leading 'to a tense situation in which citizens have become more sensitive to tax fairness issues', OECD, supra n. 4 , at 8 .

34 OECD, supra n. 4 , at 8.

35 See (17 Oct. 2014), http://www.taxjustice.net/2014/10/17/fair-taxes-key-fair-share/ (accessed 31 Aug. 2017).

36 Some examples are for instance the reports of the Tax Justice Network on Offshore Finance and Tax havens and the publication of Panama Papers and Bahama Papers that have also resulted in more discussion regarding the use of offshore tax structures.

37 European Commission Recommendation of 6 Dec. 2012 on Aggressive Tax Planning C (2012) 8806 Final at 2.

38 See EU Commission Website for anti-avoidance package at, http://ec.europa.eu/taxation_customs/taxation/company_tax/anti_tax_avoidance/index_en.htm (accessed 31 Aug. 2017).

39 Neither in the text of the Proposal for the Anti-Tax Avoidance Directive (ATAD) or the text of the ATAD 1 provide in the Art. 2 of definitions for a definition of aggressive tax planning. Crf. Proposal for a Council Directive laying down rules against tax avoidance practices that directly affect the functioning of the internal market COM/2016/ 026 final - 2016/011 (CNS). For ATAD 1, see the text of the adopted Council Directive (EU) 2016/1164 of 12 July 2016 laying down rules against tax avoidance practices that directly affect the functioning of the internal market. OJ L 193, 19 July 2016. For ATAD 2, see the text of adopted by the Council Directive amending Directive (EU) 2016/1164 as regards hybrid mismatches with third countries dated 12 May 2017. See the text of the http://data.consilium.europa.eu/doc/document/ST-6661-2017-INIT/ en/pdf (accessed 31 Aug. 2017).

40 P. Pistone, La planificación fiscal agresiva y las categorías conceptuales del Derecho tributario global, Revista Española de Derecho Financiero 170 (Apr.-June 2016),

41 According to Pistone, tax avoidance has three elements: (1) friction between form and substance to obtain tax advantage; (2) purely artificial transactions lacking valid economic reasons and (3) the intention to avoid tax duly reflected in objective elements. Furthermore, Pistone argues that aggressive tax planning differs from tax avoidance since the former entails three different elements: (1) the exploitation of cross-border tax disparities to obtain bilateral tax advantages; (2) misalignment between taxing powers and value creation and (3) unintended tax advantages from double non-taxation. Chapter 4: The Meaning of Tax Avoidance and Aggressive Tax Planning in European Union Tax Law: Some Thoughts in Connection with the Reaction to such Practices by the European Union, in Tax Avoidance Revisited in the EU BEPS Context 94-95 (A. P. Dourado ed., IBFD 2017). 
Another tax scholar, Piantavigna examined the boundaries between tax abuse and ATP. Included in his scope of tax abuse are transactions where the tax benefit is within the boundaries of the rules, but not in accordance with the object and purpose of the rules. He adds that, unlike tax abuse, 'Aggressive tax planners do not go beyond the limits fixed by rules, they go between rules (i.e. 'inter leges'). This gives rise to 'aggressive' tax planning, which consists of exploiting gaps in the architecture of the existing tax legislations, mismatches and disparities (i.e. differences resulting from the concurrent exercise of two or more taxing jurisdictions) of the international tax system. ATP reveals its essential nature of 'arranging', 'organizing', 'placing' ('planning', precisely) for tax purposes. It consists of active purposive behaviour (as opposed to passive unintentional behaviour), as '[m]aking mistakes because of ignorance of tax rules is very different from aggressive tax planning and tax fraud'. ${ }^{4}$

To test these issues, the comparative overview below aims to, firstly, examine the GAARs introduced in the countries of research and, secondly, how the GAARs in these countries have been used, if at all, to tackle ATP (section 3). The findings from this overview will support the discussion as to whether the use and implementation of these GAARs has provided certainty and clarity to the taxpayer and tax administration (section 4).

\section{Rules applicable to aggressive tax PLANNING IN THE SURVEYED COUNTRIES}

\section{I Domestic General Anti-Avoidance Rules (GAARs)}

\section{I.I GAARs in the Surveyed Countries}

All surveyed countries have included or are in the process of including GAARs in their statutory laws. Colombia, Uruguay and South Africa have existing GAARs.

Brazil is still in the process of including a statutorybased GAAR. In Brazil, Complementary Law No. 104 (enacted on 10 January 2001) introduced an additional paragraph to Article 116 of the Tax Code, a GAAR to address sham/simulated transactions. The provision required the procedure to apply this GAAR to be established by ordinary law. To this end, Provisional Measure No. 66 in 2002 was introduced, but as this Measure also added concepts such as business purpose and abuse of form that were beyond the scope of the sham doctrine, this Provisional Measure was rejected by the Parliament. ${ }^{43}$ Until the relevant regulatory measures are introduced (which at August 2017 had not yet occurred), the Brazilian GAAR remains inapplicable. ${ }^{44}$

In Colombia, before 2012, the doctrine of simulation, as provided in private law, was made applicable to taxation with little success, as the application required the prior declaration of the existence of a simulated legal act by a civil court. ${ }^{45}$ Since the tax reform of 2012 , two specific doctrines i.e. abuse of law and substance over form ${ }^{46}$ have been introduced in the Tax Code in the form of a GAAR (Article 869). Uruguay introduced the substance over form doctrine in the Tax Code (Article 6(2)).

South Africa has several rules and principles in the Income Tax Law, Tax Administration Act and case law to mitigate against tax avoidance. The statutory GAAR in the Income Tax Act considers any arrangement resulting in a tax benefit as potentially an avoidance arrangement. To be classified as an impermissible avoidance arrangement, the transaction must have any one of a number of avoidance characteristics, such as result in misuse or abuse of the provisions of the Income Tax Act; create rights or obligations not normally found in transactions between persons acting at arm's length; in a business context was entered into or carried out in a manner or means not normally employed for business purposes (other than to obtain a tax benefit) or lacks commercial substance. Apart from this statutory test, the South African courts can also use common law legal principles to counter tax avoidance, such as the test for a simulated transaction or substance over form. ${ }^{47}$ Moreover, the South African Tax Administration Act provides for 'Reportable Arrangements', which aims to tackle potentially ATP arrangements as identified by the tax administration.

\section{Notes}

42 P. Piantavigna, Tax Abuse and Aggressive Tax Planning in the BEPS Era: How EU Law and the OECD Are Establishing a Unifying Conceptual Framework in International Tax Law, Despite Linguistic Discrepancies, 9 World Tax J. (2017).

43 According to L. E. Schoueri \& R. A. Galendi, provisional Measure No. 66 was enacted by the Government in 2002 with the purpose of fulfilling 'the requirement set forth by the sole paragraph of Article 116 of the National Tax Code'. In its Arts 13 to 19, this provisional statute provided for situations in which the administrative authority could disregard legal acts or transactions carried out by the taxpayer. Such provisions, allegedly consistent with the concepts set forth in countries that have successfully regulated tax avoidance, were aimed at situations that, 'whilst licit, pursue a more favourable tax regime and involve abuse of forms or lack of business purpose'. Art. 14 of Provisional Measure No. 66 included expressions such as 'lack of business purpose' (defined as the 'option for a more complex or more expensive form, between two or more forms available for the taxpayer') and 'abuse of forms' (described by the statute as 'the indirect act which produces the same economic result as the dissimulated act or legal transaction'). L. E. Schoueri \& R. A. Galendi Junior, Chapter 9: Brazil, in Tax Avoidance Revisited in the EU BEPS Context 203 (A. P. Dourado ed., IBFD 2017).

44 Ibid., at s. II.2

45 Paniagua and Mayorga stated that in 'civil law, simulation occurs when a contract is established containing statements or declarations which conceal the true intent of the parties while constituting a seemingly valid legal form'. J. Paniagua-Lozano and H. Mayorga-Arango, Colombia, Form and Substance in Tax Law, in Cabiers de droit Fiscal International. International Fiscal Association, Vol. 87a, 217 (The Hague: SDU, 2002).

46 These rules were introduced by means of Law 1607 of 2012. See for an overview of the Law 1607, I. Mosquera Valderrama, Sweeping Tax Reforms Take Effect, Tax Notes Int'l 433 (4 Feb. 2013).

47 See C. West \& J. Roeleveld, Chapter 24: South Africa, in Tax Avoidance Revisited in the EU BEPS Context 617 (A. P. Dourado ed., IBFD 2017). 
One important difference in the application of these doctrines is that the analysis of the legal substance (sham/ simulation) versus economic substance ((business purpose, substance over form) may result in different outcomes on the application of these doctrines to artificial transactions. For instance, the sham/simulation (legal approach) doctrine aims to apply the actual legal reality and not the constructed legal reality of the taxpayer. ${ }^{48}$ In contrast, applying the substance over form or the business purpose doctrine to the transaction may result in re-characterization of the transaction or one element of the transaction by the tax administration to give effect to the substance and purpose of the transaction. ${ }^{49}$

In addition to the differences in the application of these doctrines, in general, as rightly stated by the 2002 IFA General Report, the application of the anti-avoidance rules may be the result of the difference between common law and civil law countries, for instance in respect of fraus legis for civil law countries and substance over form for common law countries. ${ }^{50}$ Furthermore, the 2002 IFA General Report also stated that in common law countries such as the United States, a separate number of doctrines exist side by side: the 'step transaction' doctrine, the 'business purpose' doctrine, the 'substance over form' doctrine, the 'economic substance' or 'economic sham' doctrine. $^{51}$

However, this distinction between common law and civil law is not applicable in Brazil, Colombia or Uruguay. Colombia and Uruguay, despite being civil law countries, make use of a substance over form rule. In Colombia, use of this rule is complementary to the abuse of law rule, giving greater strength to the anti-avoidance tools available to the tax administration. For Uruguay, the substance over form rule is treated as the main rule. In
Brazil despite being a civil law country, the tax administration has introduced in practice the business purpose doctrine mainly due to the impossibility to apply the statutory Brazilian GAAR rule of sham/simulation. The description of the implementation of these rules by the countries of research is provided in section 3.1.2 below.

\section{I.2 Implementation of the GAARs}

While these broad anti-avoidance rules in each of the surveyed countries would appear to have the potential to be far-reaching in preventing tax avoidance, their implementation appears problematic. Implementation problems have the immediate effect of producing uncertainty and a lack of clarity for the taxpayer as to the scope of the GAAR and how the tax administration and/or judiciary will implement it.

In Brazil, even though the doctrine of sham/simulation was introduced in Complementary Law No. 104 (enacted on 10 January 2001), the regulation given it effect is not yet in force. However, in practice the tax administration and the Brazilian Administrative Council of Tax Appeals (Conselho Administrativo de Recursos Fiscais CARF) have used the business purpose doctrine without any article in the Tax Code or in case law justifying its use. ${ }^{52}$ This 'business purpose doctrine' was developed in common law legal systems, which does not fit in the civil law system of Brazil. In addition, this doctrine is more difficult to implement than the sham/simulation doctrine since not only the business itself, but also the purpose of the business, plays a role in determining whether the transaction should be re-characterized as unacceptable tax avoidance or ATP. ${ }^{53}$

\section{Notes}

48 The 2002 general reporter addressed sham/simulated transactions stated with respect to these transactions, 'the core of the concept is that the form which a legal relation is given does not cover the reality intended by the parties. As often defined in civil law codes, the concept of sham/simulation covers two main situations: in the first one, there is no reality at all and in the second one, the simulated transaction covers another, hidden, transaction or relationship'. Zimmer, supra n. 22 , at 29.

49 For instance, in South Africa, if the GAAR is applicable the South African Revenue Service (SARS) 'may (i) disregard, combine or recharacterize the arrangement or any step thereof; (ii) disregard any accommodating or tax-indifferent party or treat this party and any other party as one and the same person; (iii) determine the parties who are connected persons in respect of each other as one and the same person; (iv) reallocate any income or expenditure between the parties; (v) recharacterize any income of a capital nature as income of a revenue nature; (vi) treat the transaction as if it has not been carried out, or in any other manner that in the SARS's view is adequate for the prevention or disminution of the tax benefit'. P. J. Hattingh, South Africa - Corporate Taxation s. 7, Country Surveys IBFD (https://online.ibfd.org/document/gtha_za_s_7 accessed 31 Aug. 2017).

50 In this regard, the 2002 IFA General Report stated that in many civil law countries, written or unwritten tax avoidance rules have their roots in the Roman law concept of dispositions in fraudem legis'. The 2002 IFA General Report also stated that 'In common law countries, there is no fraus legis doctrine with Roman law roots. Instead, a concept of substance over form and other doctrines has emerged in the USA'. Zimmer, supra n. 22, at 42-43.

51 According to the 2002 IFA General Report 'The relation between them is not clear. Certainly, they overlap each other to a large extent and it is common for the tax authorities to invoke as many of them as possible in the specific case, in order to make it possible for the court to "choose from the cafeteria of tax avoidance doctrines", as the branch reporters put it'. Zimmer, supra n. 22, at 43.

52 So it happened in the Lupatech case (Judgment 1402-001.404 of 7 Sept. 2013), where the Brazilian Administrative Council of Tax Appeals (Conselho Administrativo de Recursos Fiscais CARF) found that 'the acts carried out are licit and coherent with the private law', but disregarded the transaction by considering it 'artificial' due to 'the lack of business purpose'. Other judgments indicate that the BRS has been applying tests of substance in connection with the business purpose doctrine to disregard the tax effects of formal holding or trading companies. Authorities underline the absence of staff, equipment and premises of the relevant company, as if positive activities were required for legal entities to fulfil their purposes. The approach is adopted even when the structure is compliant with specific anti-avoidance rules. In the Marcopolo case (Judgments 105-17.083 and 105-17.084 of 25 June 2008), the CARF disregarded trading companies in view of the lack of 'operational capacity able to perform the activities to which they were assigned', notwithstanding the transfer pricing control by the taxpayer.

53 The Carrefour case (Judgment 103-23.290, of 12 May 2007) demonstrates that the Brazilian Administrative Council of Tax Appeals (Conselho Administrativo de Recursos Fiscais CARF) is even prepared to distort the sham doctrine as means to enforce the business purpose argument: the decision was reasoned on 'the absence of any business or corporate purpose in the merger undertaken', but eventually concluded that 'the case should be qualified as sham'. The misuse of intricate doctrines and its consequences on legal certainty and equality, considered central to the rule of law, are discussed by Schoueri and Barbosa. It is felt from decisions in Brazil that authorities have a priori 
The interpretation of the business purpose doctrine by the Brazilian Administrative Council of Tax Appeals (Conselho Administrativo de Recursos Fiscais CARF) has raised uncertainty with respect to the position of the taxpayer. In 2016, Schoueri and Galendi stated that there is a "movement of the court towards a "substance over form" approach, whereby doctrines such as "business purpose" and "abuse of law" began to be invoked by the judges to disregard transactions undertaken by the taxpayer in which no other reason than the tax reduction could be found'. The report, when analysing the CARF's approach, also concluded that notwithstanding the lack of regulation in Brazilian law, the business purpose argument has been 'taken into account by CARF, sometimes under the label of sham sometimes with no legal basis at all'. ${ }^{54}$ Such application has created uncertainty for taxpayers in their transactions since the decisions of the CARF do not reflect a co-ordinated or consistent approach - in some cases transactions considered as sham will be tackled under the business purpose, and in other cases the business purpose is applied even if the transaction is not regarded as a sham. ${ }^{55}$

The abuse of law and the substance over form doctrines were introduced into the Colombian Tax Code in 2012 (modified in 2016). ${ }^{56}$ Abuse for tax purposes is the use or implementation, by means of one operation or a set of operations of any entity, legal act or procedure that aims to change, disguise or modify artificially the tax consequences that will be generated for the taxpayer or related parties, shareholders, or real beneficiaries. The tax reform enacted in December 2016, explicitly removes the intention to defraud as an element of abuse, leaving only the burden of demonstrating the artificial form for the transaction and the tax advantage obtained by the taxpayer. Article 869-1 of the Colombian Tax Code has now substituted the criteria for the presumption of abuse of law ((1) the transaction is between related parties; (2) the transaction makes use of tax havens; (3) the transaction includes a special entities regime or an exempt tax entity; (4) the price agreed differs by more than $25 \%$ from the arm's length price; (5) the conditions agreed by the parties would have not been agreed by third parties in similar circumstances.${ }^{57}$ ) for a rather flexible procedure that only requires the tax authorities to indicate the reasons why they believe a transaction is abusive with mere preliminary evidence. In all cases of abuse, the burden of proof to disprove abuse rests on the taxpayer, once the tax authorities have indicated why they suspect the presence of abuse.

The 2012 Tax Reform in Colombia also introduced the following factors indicative of abuse for tax purposes (1) presence of one or more transactions (step-transaction doctrine); (2) artificial alteration or modification of tax effects; (3) one or more taxpayers and their related parties, shareholders, partners or beneficial owners; (4) intention to obtain a tax advantage; and (5) absence of a main, legitimate and reasonable business purpose. These, however, were removed from the tax code with the 2016 tax reform, probably with the intention of freeing the tax administration from the requirement of fitting the taxpayer conduct into a structured theory of abuse. This decision, of course, had a large negative impact on legal certainty, as taxpayers cannot know the criteria that the tax administration will use to determine if a structure or transaction is artificial or abusive.

While there are no public cases documenting the application of the GAAR to any transaction, several aspects in the application of the Colombian GAAR are problematic including: the lack of business knowledge by tax administration officials in charge of re-characterization; the uncertainty produced by the definition of the most 'natural' legal form to achieve a business purpose; the difficulties in establishing a fair market value and the possible differences with International Financial Reporting Standards (IFRS) thirteen valuations; ${ }^{58}$ and the uncertainty as to whether the courts will produce their own jurisprudence on what constitutes an artificial arrangement.

Article 6(2) of the Tax Code in Uruguay provides for the substance over form doctrine. However, it is not clear whether the application of the anti-abuse rule is aimed at tackling only tax avoidance or also tax evasion. In practice, the tax administration has used this rule as an anti-evasion clause. These rules are not specifically applicable to ATP since the main element for the application of the anti-avoidance rule is whether the behaviour of the taxpayer implies the use of an inappropriate legal form. The inappropriate legal form may not of itself be indicative of ATP.

\section{Notes}

judgment over certain tax planning structures and the business purpose doctrine is fit to give grounds to virtually any challenge, in a growing insecurity for taxpayers. L. E. Schoueri \& M. C. Barbosa, Chapter 6: Brazil, in GAARs - A Key Element of Tax Systems in the Post-BEPS World 109-145 (M. Lang et al., Amsterdam: IBFD 2016).

54 L. E. Schoueri \& R. A. Galendi Junior, Brazil Section II.3. addressed the approach of the Brazilian Administrative Council of Tax Appeals (Conselho Administrativo de Recursos Fiscais CARF) towards tax planning. This report stated that despite the decisions of the CARF lacking legal basis, the taxpayer does not go to the judiciary to annul the decisions of the CARF. One of the reasons could be the REFIS programme (Programa de Recuperação Fiscal) aiming to pay the tax debts in instalments. To participate in the REFIS programme, the taxpayer is required to waive the right to appeal to the Judiciary. Schoueri \& Galendi Junior, supra n. 43 , at 209.

55 S. 9.2.3.1. Schoueri \& Galendi Junior, supra n. 43, at 205-207.

56 Arts 869, 869-1 and 869-2) Law 1607 of 2012 modified by means of Art. 300 of the Law 1819 of 2016.

57 Mosquera Valderrama, supra n. 46

58 International Financial Reporting Standard 13 Fair Value Measurement 'applies to IFRSs that require or permit fair value measurements or disclosures and provides a single IFRS framework for measuring fair value and requires disclosures about fair value measurement. The Standard defines fair value on the basis of an "exit price" notion and uses a "fair value hierarchy", which results in a market-based, rather than entity-specific, measurement'. https://www.iasplus.com/en/standards/ifrs/ifrs13 (accessed 31 Aug. 2017). 
South Africa introduced a new GAAR in 2006 (section $80 \mathrm{~A}$ to $80 \mathrm{~L}$ of the Income Tax $\mathrm{Act}^{59}$ ). This GAAR replaced the old GAAR (section 103(1) of the Income Tax $A c t^{60}$ ). While the old GAAR was supported by case law, no cases have been heard with respect to the application of the new GAAR. However, as many of the principles of the old GAAR were retained in the new GAAR, the case law regarding the old $\mathrm{GAAR}^{61}$ remains applicable in many instances 'to answer selected aspects with respect to the application of the statutory rules or clarifies the court's position on the application of the common law doctrines'. ${ }^{62}$

The current GAAR of section $80 \mathrm{~A}$ of the Income Tax Act provides that an impermissible tax avoidance arrangement is one if its main purpose is to obtain a tax benefit and is abnormal, or lacks commercial substance, or creates rights and obligations which are not arms-length. The current rule applies to any arrangement entered into on or after 2 November 2006. The tax authorities have been slow to challenge a taxpayer under the new anti-abuse rule instead, the tax authorities have chosen to introduce specific legislation to tackle tax avoidance. This may be based on a view of the GAAR as a deterrent instead of an active rule. In addition to the statutory GAAR, additional common law principles may be applied to counter tax avoidance. These principles apply in cases where there is, for example, a simulated transaction.

\subsection{Application of GAARs to Aggressive Tax Planning}

\subsection{Aggressive Tax Planning Schemes and Application of GAARs}

For this article, it is first questioned whether the GAARs, where existing in the surveyed countries, are useable for ATP as described by Pistone and Piantavigna. ${ }^{63}$ Secondly, in examining the use of GAARs to prevent or mitigate
ATP, has such use resulted in more uncertainty for taxpayers and tax administrations on what constitutes ATP and the circumstances under which it becomes unacceptable tax avoidance?

The research in section 3.1 shows that there is not clarity on whether the GAARs can be used against ATP. The research shows that no distinction between tax avoidance, tax abuse and ATP appears in the legislation of the surveyed countries. The existence of a statutorybased rule, such as a GAAR or the anti-avoidance judgemade doctrine may imply that the country has tools necessary to defend against ATP, tax abuse and/or tax avoidance in some measure. Certainly, the statutory GAAR and judge-made doctrine include the ability to tackle artificiality within an activity/transaction that may have resulted from either unacceptable tax avoidance or ATP.

The research in section 3.1 shows that from a tax policy perspective the countries have struggled to find the right balance between the introduction of tax measures to tackle ATP and the introduction of transparent measures that provide clarity and reliability for the taxpayer.

It is important that countries establish common boundaries between unacceptable tax avoidance and ATP to harmonize, and possible expand, the application of the GAARs to these two concepts. This expansion may result in an additional tool to tackle ATP as a whole even beyond the boundaries of tax avoidance as currently contemplated by the countries of research. ${ }^{64}$

In respect of ATP, the focus has been in the use of tax schemes to deal with the use of low tax jurisdictions; or the use of tax treaties (treaty shopping) with less restrictive treaty abuse provisions. ${ }^{65}$ In addition, of the countries of research (Brazil and South Africa) have also made distinctions regarding ATP by individuals and/or corporate (small or large corporations).

For instance, the Brazilian tax authority focusses more on companies with respect to tax avoidance than

\section{Notes}

59 Ss $80 \mathrm{~A}$ to $80 \mathrm{~L}$ defines an impermissible avoidance arrangement as any arrangement that meet the following four requirements: (1) an avoidance arrangement (as defined) is entered into or carried out; (2) it results in a tax benefit; (3) any one of the following 'tainted elements' is present (a) abnormality regarding means, manners, rights or obligations; (b) a lack of commercial substance in whole or in part; (c) misuse or abuse of the provisions of this Act; (4) the sole or main purpose is to obtain a tax benefit. L. van Schalkwyk \& B. Geldenhuys, Section 80A (c) (ii) of the Income Tax Act and the Interpretation of Tax Statutes in South Africa, 17(2) Meditari Acct. Res. 167-168 (2009).

60 S. 103(1) stated the old general anti-avoidance rule. For a transaction to fall under s. 103(1), the transaction will be evaluated in accordance to the following criteria: (1) there has to be a transaction, operation or scheme entered into or carried out; (2) the effect of the transaction is avoiding or postponing or reducing the liability for the payment of any tax imposed by the Act; (3) the abnormality test or arm's length test under a transaction, operation or scheme; and (4) the transaction must have been entered into solely or mainly for the purposes of avoiding, postponing or reducing the amount of tax liability. J. C. Kanamugire, A Critical Analysis of Tax Avoidance in the South African Income Tax Act 58 of 1962, as Amended, Vol. 4 (6) Mediterranean J. Soc. Sci. (2013), http://www.mcser.org/journal/index.php/mjss/article/viewFile/313/329 (accessed 31 Aug. 2017).

61 E.g. 'Meyerowitz v CIR (1963 AD) 25 SATC 287, dealt with the concept of abnormality, in Hicklin v SIR (1980 AD) 41 SATC 179 it was decided that where persons are acting at arms length there is a presumption that any rights and obligations created between them are normal and because the element of abnormality was not present the GAAR could not apply. In CIR $v$ Conbage (Pty) Ltd (1999) 61 SATC 391, the substance of an arrangement and the true intention of the parties was examined and it was found that the scheme was not a "sham" transaction and although tax was saved this did not turn it into an abnormal transaction'.

62 West \& Roeleveld, supra n. 47, at 617-618.

63 See s. 2.2, supra. Pistone, supra n. 40, at 170 and Piantavigna, supra n. 42.

64 The use of GAARs to tackle aggressive tax planning will be addressed in the 2018 IFA Seoul Congress. Subject 1 which deals with Anti-avoidance measures of general nature and scope. GAAR and other rules.

65 An example will be the use of beneficial ownership instead of the limitation on benefits provision. In this case, the requirements for beneficial ownership can be less restrictive than the requirements of limitation on benefits. 
individuals, it being considered that companies have more resources and more room for tax planning than individuals. The Brazilian tax authorities challenge not only the interpretation of the tax legislation but also the characterization of a legal relationship as described by the taxpayer. $^{66}$

Another example is the South African GAAR which appears to target schemes characteristic of ATP (whether domestic or cross border). The GAAR, in considering whether a scheme lacks commercial substance, ${ }^{67}$ will find indicative schemes which include roundtrip financing schemes ${ }^{68}$ or the presence of an accommodating or tax indifferent party ${ }^{69}$ in the arrangement. In the past, both such factors were implicitly considered in the application of GAAR, but the new GAAR explicitly identifies such practices as lacking commercial substance adding to the likelihood of the scheme being an impermissible tax avoidance scheme.

\subsubsection{Disclosure Obligations by the Taxpayer and/or Tax Adviser}

Another issue that was also addressed in this survey was the existence or not of measures targeting tax consultants in the surveyed countries. Colombia, Brazil, Uruguay and South Africa do not have rules to target tax consultants; however, in Uruguay the behaviour of the consultant may be punishable if such behaviour is qualified as an offence or crime. In South Africa, the Tax Administration Act has a section dealing with unprofessional conduct (Chapter 18 section 239 to 243). In addition, the Act also includes rules to ensure that tax practitioners are registered with reputable bodies (section 240(1)). The situation may change due to the introduction of BEPS Action 12 that provides for disclosure of tax arrangements by tax consultants. ${ }^{70}$

Successful application of GAAR is reliant, in part, on the disclosure by the taxpayer of the tax scheme disclosed by the taxpayer to the tax authorities and on the analysis by the tax administration of the tax scheme to assess whether it constitutes unacceptable tax avoidance or ATP. It is submitted that clear and consistent disclosure requirements equally provide clarity for the taxpayer as to the application of the GAAR. In addition, early disclosure or advanced disclosure of transactions prior to the end of a year of assessment may also mitigate against or better enforce the application of the GAAR. However, in this respect it appears that the surveyed countries may have to improve their domestic disclosure and room exists for the development of general disclosure rules concerning potentially ATP schemes (see also section 5 below).

With respect to potential ATP schemes, companies in South Africa are subject to disclosure requirements in respect of certain ${ }^{71}$ reportable arrangements. ${ }^{72}$ The mirror of the language with that of the GAAR provides clear evidence that such disclosure is geared at early identification of a potential aggressive tax scheme and provides further guidance of impermissible tax avoidance.

In contrast with respect to potential ATP schemes, Colombia $^{73}$ and Uruguay only have disclosure requirements in respect of transfer pricing. ${ }^{74}$ While Brazil requires companies to maintain and furnish all accounting information to the tax administration, ${ }^{75}$ there are no

\section{Notes}

66 It is argued that challenging the legal relationship became usual in the sport business after sportsmen managed to incorporate legal entities to enjoy corporate taxation on a deemed income basis. See L. E. Schoueri, Taxation of High Net Worth Sports Persons in Brazil, 2 Global Sports L. \& Tax'n Reports, 9-12 (2011). In the Felipão case (Judgment 106-14.244 of 10 Oct. 2004) and Guga case (Judgment 106-17.147 of 5 Nov. 2008), the Brazilian Administrative Council of Tax Appeals (Conselho Administrativo de Recursos Fiscais CARF) disregarded the structure under the argument that the legal entity would only intend to cover personal services rendered. After the tax planning as such was authorized by legislation in 2005 , challenges started to question the nature of the payments received instead of the structure itself. In the Neymar case (Judgment $2402-$ 005.703 of 15 Mar. 2017), a legal entity incorporated to exploit image rights had income attributed to the individual taxpayer since paid after 'pre-established percentages' without 'relation to the effective exploitation of the right'.

67 S. $80 \mathrm{C}$ of the South African Income Tax Act 58 of 1962.

68 S. $80 \mathrm{D}$ of the South African Income Tax Act 58 of 1962

69 S. $80 \mathrm{E}$ of the South African Income Tax Act 58 of 1962.

70 For instance, at the IFA Latin-American Congress that took place in May/June 2017 in Buenos Aires, Argentina, the application of BEPS Action 12 in Latin American countries was discussed and some differences in approach towards the disclosure of tax arrangement by tax consultants were noted. See General Report Alejandro Messineo. General Report and country reports available at the website of IFA Latin-American at http://apps.kingconf.com/ifa2017indice/ (accessed 31 Aug. 2017).

71 Latest notice (3 Feb. 2016) found at: http://www.sars.gov.za/AllDocs/LegalDoclib/SecLegis/LAPD-LSec-TAdm-PN-2016-02\%20-\%20Notice\%20140\%20GG\%2039650\% 203\%20February\%202016.pdf (accessed 31 Aug. 2017)

72 The arrangement will be reportable if a 'tax benefit' is derived and (1) the calculation of interest is dependent on the tax treatment of the arrangement; (2) the inclusion or presence of round trip financing or an accommodating or a tax indifferent party or it contains elements that have the effect of offsetting or cancelling each other; (3) gives rise to an amount disclosed as a deduction for income tax but not as an expense for purposes of 'financial reporting standards' or revenue for 'financial reporting standards' but not as gross income for purposes of the Income Tax Act; (4) does not result in a reasonable expectation of a 'pre-tax profit' for any 'participant'; (5) results in a reasonable expectation of a 'pre-tax profit' for any 'participant' that is less than the value of the tax benefit where both are discounted to present value at the end of the year of assessment.

73 The 2012 Tax Reform Colombia established new disclosure obligations related to transfer pricing for all transactions involving the transfer of a Colombian asset to foreign jurisdictions, regardless of whether the transaction involves related parties or if it is valued at a price that does not exceed the minimum threshold for transfer pricing reporting.

74 Transfer pricing will be discussed in another forthcoming (2018) article in the framework of the DeSTaT project.

75 Since 2007, a major Public Digital Bookkeeping System (Sistema Público de Escrituração Digital SPED) runs the reception and storage of numerous books and documents. SPED comprises electronic versions of (1) financial statements and tax returns (uploaded annually for purposes of the corporate income tax), (2) tax records as the entry, exit and inventory books (uploaded monthly for purposes of the federal excise tax and state sales tax), and (3) invoices registering sales and services performed. Under SPED, information that was previously provided to federal, state and local tax authorities, in physical and separate documents, is provided in standardized and electronic files. The system is administered by the Federal Revenue Service, and is easily accessible by state and municipal authorities upon conclusion of an agreement. SPED integrates the 
specific rules regarding the disclosure by the taxpayer of tax planning schemes. ${ }^{76}$

From a tax policy perspective, the differences in approach towards disclosure needs to be revisited by the surveyed countries. Requirements for disclosure by the taxpayer of ATP may benefit the tax administration and the taxpayer since on the one hand, the tax administration will receive information on how the taxpayer operates, and on the other hand, the taxpayer could receive a consultative ruling stating whether the tax administration has concerns that such structure can result in ATP. Such a consultative (non-binding) ruling enables the taxpayer to discuss any concerns the tax administration may have with the tax structure. Such an approach requires a certain level of trust between the authorities and the taxpayer. Should such a structure be applied but the taxpayer experiences an increase in tax audits or the tax administration become confrontational with respect to the consultative rulings, the system may fail. Such concerns should be addressed by the OECD when dealing with the implementation of BEPS Action 12 that provides for disclosure of aggressive tax schemes.

In respect of GAAR, we argue that it is important to have clear and simple rules as to the application of GAAR to ATP schemes. The failure to approve the statutory GAAR in Brazil and the lack of clarity in Uruguay on whether the behaviour is regarded as a tax offence or not, are inconsistent with the objectives of fiscal transparency.

\section{Fiscal tRANSPARENCY AND EXCHANGE OF INFORMATION TO TACKLE AGGRESSIVE TAX PLANNING IN THE COUNTRIES OF RESEARCH}

\section{I Introduction to Fiscal Transparency}

Dharmapala ${ }^{77}$ expresses the concern that global fiscal transparency is less effective in preventing sophisticated corporate ATP activity as opposed to evasion-related activities carried out by individuals in tax havens. While this may currently be true, the increased network of exchange of information instruments and the growing automatic exchange of information may start to challenge this view. It is clear, however, both in terms of the foregoing sections of this article and the evidence from the surveyed countries below that in the absence of early disclosure procedures or a mechanism to collect relevant data to flag potential schemes, it is likely that the necessary information will not be easily apparent to the tax administration relegating exchange of information to a tool of last resort rather than a proactive measure.

The surveyed countries cannot confirm the since the instruments for exchange of information have only been recently implemented by them. An extension of information to be supplied (and increased penalties for non-disclosure) in the annual return to be submitted by corporate taxpayers may also be a deterrent to aggressive tax schemes.

Mere exchange of information is not enough to tackle ATP, as financial or tax information from a different jurisdiction may initially only reveal underreporting of income or hidden assets. However, an enhanced exchange of information where the administration gets data on the taxpayers' uncertain tax positions, or their use of domestic benefits may be more effective in tackling ATP. Similarly, and especially for the developing countries, the use of joint audit or other co-operative techniques between tax administrations are not yet sufficiently developed or utilized to be an effective tool against ATP.

The situation is changing as countries are not only exchanging information on request, ${ }^{78}$ but since 2014 a new global standard i.e. automatic exchange has been introduced. The surveyed countries have committed to adopt the global standard by 2017 , i.e. Colombia and South Africa, or by 2018, i.e. Brazil and Uruguay. These countries will have access to financial account information that in addition to the country by country reporting (BEPS Action 13) will allow the tax administrations to have access to more information on an automatic basis.

Despite the access to more information, we submit that the concern of Dharmapala on the effectiveness of exchange of information to tackle ATP still remains unanswered. The reason is that countries are still at the early stages of implementing automatic exchange of information and exchange of country by country reporting, and

\section{Notes}

management of tax obligations in a national level, with timely exchange of sensitive information between tax administrations. L. E. Schoueri \& M. C. Barbosa, Brazil, in Tax Secrecy and Tax Transparency: The Relevance of Confidentiality in Tax Law, vol. 1, 169-208 (E. Kristoffersson et al., Frankfurt am Main: Peter Lang GmbH 2013).

76 Government introduced a Provisional Measure (No. 685) in 2015 attempting to oblige taxpayers to report transactions involving elimination, reduction or deferral of taxes. Should authorities disagree with the relevant transaction, the taxpayer would be summoned to pay taxes due (and interest) within thirty days. The lack of declaration entailed a presumption of fraud, with a penalty of $150 \%$. The rule identified reportable transactions after general notions like 'relevant reasons other than tax' or 'typical contract'. In the lack of an applicable GAAR and deviating from BEPS Action 12 itself, the proposed disclosure was not clear with respect to what should be reported by taxpayers. As the previous Provisional Measure No. 66, the Provisional Measure No. 685 was eventually rejected by Parliament.

77 D. Dharmapala, Presentation: Tax Havens and the Economic Perspective at the Executive Training Seminar Series: Tax Havens: Selected Theoretical and Practical Key Issues. A Legal and Economic Perspective (June 2011). Organized by the Academy of Global Governance. European University Institute.

78 All surveyed countries i.e. Brazil, Colombia, Uruguay, and South Africa are members of the OECD Global Transparency Forum. All countries have been reviewed in phase 1 and 2 by the Peer Review Group. Colombia and South Africa are compliant whereas Brazil, and Uruguay are largely compliant with the OECD Standard on Exchange of Information. The Peer Review Group examines the legal and regulatory framework for exchange and the exchange of information in practice. Information available http:// www.oecd.org/tax/transparency/exchange-of-information-on-request/peer-review/ (accessed 31 Aug. 2017). 
therefore, it is too early to test the effectiveness of exchange of information. ${ }^{79}$

\subsection{Access to International Databases}

The tax administration of the countries may have access to international databases such as the OECD database on ATP schemes (ATP Directory) ${ }^{80}$ and the database run by the OECD Joint International Taskforce on Shared Intelligence and Collaboration (JITSIC). ${ }^{81}$ The JITSIC is a Centre created in 2014 by the OECD and open on a voluntary basis to all members of the OECD's Forum on Tax Administration. From the countries belonging to the Forum i.e. Brazil, Colombia and South Africa, only South Africa has become a member of the JITSIC. Uruguay is not a member of the OECD Forum on Tax administration nor of the JITSIC.

However, even where it can be confirmed that the tax administration has access to such databases, for example Colombia has access to the OECD reports on ATP and South Africa has joined JITSEC, there is no information in the public domain as to the use or application of these databases by the tax authorities of the surveyed countries. No information is available on what mechanisms the tax authorities may be using or which international databases are being accessed by the Tax Authorities to identify tax shelters or ATP.

\subsection{International Task Forces and Regional Initiatives}

Tax authorities of a country may be party to any formal or informal international task force to counter ATP. The developments have taken place at international (OECD) level but also at regional level. However, participation in international task forces and regional initiatives varies from country to country. The varying participation is indicative of a lack of international co-ordination or a lack of faith with respect to the success of the initiative. It is further unclear, even where there is stated participation, as to the level of commitment to the initiative.

The surveyed countries provide clear evidence of such varying participation. Colombia, Brazil and South Africa, for example, participate in OECD initiatives with the aim to strengthen the tax administration (the OECD Tax Inspector Without Borders initiative). Another example is the participation of Colombia, Brazil, South Africa, and Uruguay in OECD initiatives and regional initiatives to counter ATP (regional agreements that contribute to facilitate joint audits and simultaneous audits) and to exchange information (Common Reporting Standard which introduced the global standard on Automatic Exchange of Information).

The level of engagement in international task forces and regional initiatives may depend on the motivation behind such participation. South Africa is, for example, a significant force in regional bodies such as the South African Development Community (SADC) and the African Tax Administrators Forum (ATAF). From such engagement, South Africa has also expanded to other fora. Examples include being one of the driving forces ${ }^{82}$ of Tax Inspectors Without Borders. ${ }^{83}$ Furthermore, ${ }^{84}$ the regional multilateral agreement of SADC will most certainly facilitate future joint audits ${ }^{85}$ and simultaneous tax examinations. ${ }^{86}$ Since May 2007, South Africa has an 'enhanced engagement' with the OECD. Furthermore,

\section{Notes}

79 The issue of exchange of information and taxpayer rights and the issue of simultaneous tax examinations and joint audits will be dealt with in other articles in the framework of the DeSTaT project. See for exchange of information I. J. Mosquera Valderrama, A. Mazz, L. E. Schoueri, N. Quiñones, J. Roeleveld, P. Pistone \& F. Zimmer, The Rule of Law and the Effective Protection of Taxpayers' Rights in Developing Countries (31 Aug. 2017). WU International Taxation Research Paper Series No. 2017-10. Available at SSRN: https://ssrn.com/abstract=3034360 (accessed 31 Aug. 2017).

80 According to the OECD: 'The ATP Directory is a secure database of aggressive tax planning schemes. Access to the databases is limited to government officials from countries that are members of the Expert Group on ATP Directory. The Directory contains a database of more than 400 tax planning schemes and a section on hybrid mismatch arrangements with tables that compare the tax treatment of entities and instruments in various countries in order to facilitate the detection of hybrid mismatch arrangements'. Information available at http://www.oecd.org/ctp/aggressive/co-operation-and-exchange-of-information-on-atp.htm (accessed 31 Aug. 2017).

81 In 2014, the OECD introduced the Joint International Tax Shelter Information and Collaboration Centre (2014). 'The main objective of this Centre is to offer a platform to enable its members to actively collaborate within the legal framework of effective bilateral and multilateral conventions and tax information exchange agreements - sharing their experience, resources and expertise to tackle the issues they face in common' The OECD stated that this initiative builds on the success of the original JITSIC. Therefore, 'the member countries agreed to establish the JITSIC Network, with a wider focus on information exchange and collaboration on areas of common concern. Reflecting this change, JITSIC was renamed as the Joint International Tax Shelter Information \& Collaboration Network'. http://www.oecd.org/tax/forum-on-taxadministration/jitsic/ (accessed 31 Aug. 2017).The original initiative was the Joint International Tax Shelter Information Centre (JITSIC) established in 2004 by the governments of Australia, Canada, the United Kingdom and the United States to combat cross-border avoidance.Information available at: http://webarchive.nationalarchives. gov.uk/+/http://www.hmrc.gov.uk/avoidance/aag-jitsic.htm (accessed 31 Aug. 2017).

82 The driving forces behind the OECD initiative of 'Tax Inspectors without Borders' were 'Oupa Magashula, former Commissioner General of the South Africa Revenue Service, Nhlanhla Nene, then South Africa's Deputy Finance Minister and Pascal Saint-Amans, Director of the OECD's Centre for Tax Policy and Administration'.

83 OECD (2012), http://www.oecd.org/newsroom/taxoecdlaunchestaxinspectorswithoutborders.htm (accessed 31 Aug. 2017).

84 See J. Roeleveld \& C. West, South Africa, in Exchange of Information and Cross-Border Cooperation Between Tax Authorities vol. 98b, 19-20 (IFA Cahiers, Online Books IBFD 2013).

85 According to the OECD a joint audit (JA) 'means an arrangement whereby Participating Countries agree to conduct a coordinated audit of one or more related taxable persons (both legal entities and individuals) where the audit focus has a common or complementary interest and/or transaction. A JA shall include at least two or more Participating Countries' Sixth Meeting OECD Forum on Tax Administration. Istanbul 15 and 16 Sept. 2010. Joint Audits Participants Guide. Available at http://www. oecd.org/tax/administration/45988962.pdf (accessed 31 Aug. 2017).

86 According to the OECD simultaneous tax examination 'means an arrangement between two or more Parties to examine simultaneously and independently, each on its own territory, the tax affairs of (a) taxpayer(s) in which they have a common or related interest, with a view to exchanging any relevant information which they so obtain'. 1992 
South Africa has been extensively involved in the OECD's Forum for Tax Administration; co-chaired the joint OECD Committee on Fiscal Affairs and Development Assistance Committee; and it is a member of the G20 nation. In addition, South Africa has signed the Convention on Mutual Administrative Assistance in Tax Matters, which entered into force in March 2014 and has been involved in a number of reports generated by these bodies in the area of exchange of information and cross border cooperation between tax authorities. This involvement has also aided the improvements to the South African Revenue Service (SARS) and the increased involvement of South Africa in international trade.

Colombia provides further evidence of a country engaging in international task forces and regional activity. While currently having observer status in the OECD, Colombia is in the accession process to become an OECD Member. Demonstrating its commitment, Colombia participates actively in the working parties of the OECD, especially Working Parties 1 and 6 at the OECD. Colombia also participates in a number of regional initiatives. In this regard, Colombia aims to exchange information with countries of the Pacific Alliance (Peru, Chile, Mexico and Colombia), and with members of the Andean Community in the framework of the Decision 578 (Multilateral tax treaty model of the Andean Community). The exchange of information may result also in the exchange of aggressive tax practices experienced by the tax administration of Colombia, especially in the framework of the Convention on Mutual Administrative Assistance in Tax Matters, which entered into force in July 2014. While the tax administration has not disclosed any public information regarding this practice, anecdotal evidence suggests that the CIAT (Inter-American Center of Tax Administration ${ }^{87}$ ) meetings may involve an informal exchange of information regarding notorious audits and abusive schemes.
Like Colombia, Brazil seeks to join the OECD and has recently (May 2017) sent a formal request to become a member of the OECD. Brazil is a member of the G20 nations and has been involved in several OECD initiatives such as the Global Forum on Exchange of Information and Transparency for Tax Purposes and the Convention on Mutual Administrative Assistance in Tax Matters, which entered into force in October 2016. Uruguay has not expressed its interest to become an OECD member, but it participates in several OECD initiatives including the Global Forum on Exchange of Information and Transparency for Tax Purposes and the Convention on Mutual Administrative Assistance in Tax Matters, which entered into force also in December 2016.

\section{Aggressive tax planNing AND CO-OPERATIVE TAX COMPLIANCE}

Many of the measures discussed in this article to counter ATP rely, in part, on a sound working relationship between the taxpayer and the tax authorities. Indeed, it may be argued that in the absence of a sound and transparent relationship between the parties, the measures put in place against ATP may well fail.

The approach to a sound relationship between tax administration and taxpayer is not new. In 2008, the OECD encouraged tax administrations to establish a relationship with large business taxpayers based on trust and co-operation; the so-called 'enhanced relationship'. ${ }^{88}$ Later, in 2013, the OECD decided to include the term co-operative compliance to make clear 'that the approach is based on co-operation with the purposes of assuring compliance, which is to say payment of the right amount of tax at the right time'. ${ }^{89}$

Co-operative tax compliance between taxpayers and tax authorities should be high on the priority of any tax administration. ${ }^{90}$ Transparency between tax authorities and taxpayers leads to certainty in the disclosure requirements, application and interpretation of the law and,

\section{Notes}

OECD Model Agreement for the Undertaking of Simultaneous Tax Examinations. Available at http://www.oecd.org/ctp/exchange-of-tax-information/2666483.pdf (accessed 31 Aug. 2017)

87 According to the website of the CIAT, 'the Inter-American Center of Tax Administrations (CIAT) supports the efforts of national governments by promoting the evolution, social acceptance and institutional strengthening of tax administrations, encouraging international cooperation and the exchange of experiences and best practices'. Information available at http://www.ciat.org/index.php/en/about-ciat.html (accessed 31 Aug. 2017).

88 OECD, supra n. 31

89 See OECD, Co-operative Compliance: A Framework: From Enhanced Relationship to Co-operative Compliance 13 (Paris, OECD Publishing 2013), http://dx.doi.org/10.1787/ 9789264200852-en (accessed 31 Aug. 2017). See for the most recent OECD report on this topic, OECD, Co-operative Tax Compliance: Building Better Tax Control Frameworks (Paris, OECD Publishing 2016), http://dx.doi.org/10.1787/9789264253384-en (accessed 31 Aug. 2017).Co-operative compliance and developing countries will be addressed in another article in the framework of the DeSTaT project (Forthcoming 2018). See for cooperative compliance J. L. Pemberton \& A. Majdanska, Can Cooperative Compliance Help Developing Countries Address the Challenges of the OECD/G20 Base Erosion and Profit Shifting Initiative?, 70 Bull. Int'l Tax'n 10 (2016), Journals IBFD. See also (in Spanish) J. A. Rozas Valdés, Los Sistemas de Relaciones Cooperativas: Una perspectiva de Derecho Comparado desde el Sistema Tributario Español, Instituto de Estudios Fiscales. Document no. 6.2016.

90 In Feb. 2011, the OECD Committee of Fiscal Affairs published a report on Tackling Aggressive Tax Planning Through Improved Transparency and Disclosure. This report outlined the importance of timely, targeted and comprehensive information to counter aggressive tax planning. This report also provided an overview of disclosure initiatives introduced in certain OECD countries and the usefulness of such initiatives for both taxpayers and tax administrations. One of the main conclusions of this report is that 'disclosure initiatives can help to fill the gap between the creation/promotion of aggressive tax planning schemes and their identification by the tax authorities'. This report recommended 'to countries to continue sharing experiences on the design and implementation of disclosure initiatives to assist in creating a compliance framework that benefits both governments and taxpayers at large'. OECD, Tackling Aggressive Tax Planning Through Improved Transparency and Disclosure 19 (OECD Publishing 2011), Report available at http://www.oecd.org/ctp/exchange-of-tax-information/48322860.pdf (accessed 31 Aug. 2017). 
where extended to co-operation cross-border, consistency in the information and the penalties levied against noncompliance.

The surveyed countries represent a proxy for the current state of this relationship, for ATP, between taxpayers and tax authorities.

To date, the main objective of the tax authorities has been the extent to which information is available or to be made available to them. The focus has not been on transparency in terms of availability of clear and reliable rules for the taxpayers.

In Brazil, there is currently poor communication between the Brazilian Revenue Service (BRS) and the taxpayers pursuant to the interpretation of the tax legislation. Critically a difficulty in obtaining a consolidated position of the BRS as regards controversial issues exists. A previous mechanism to obtain 'normative opinions' was repealed. Coupled with the inefficiency of the consulting process before the BRS has resulted in a breakdown of the relationship between the tax authority and the taxpayer. In an attempt to rectify this breakdown, the Normative Ruling No. 1396 of 2013 assigned authority to the general Coordination of the Taxation Body (Coordenação-Geral de Tributação Cosit) power to answer questions addressed to the BRS by means of a consultative ruling, which answer binds the tax administration. These consultative rulings must be published on the website of the BRS (apart from specific data relating to the identification of the taxpayer, such as process number, cadastral data, etc.). Publication of the relevant answers allows rulings to be claimed as a precedent by taxpayers in similar situations.

Equally, in Colombia, taxpayers do not fully trust the tax administration. This lack of trust has prevented the development of a proactive enhanced cooperation for the tax system of Colombia. The only existing tool which may be seen as supportive of enhanced cooperation is the use of Advanced Pricing Agreements (APAs) between the taxpayer and the tax administration in issues of transfer pricing. Before the 2012 Tax Reform, only one APA had been concluded, ${ }^{91}$ and as of now (August 2017), only three more applications are being processed by the tax administration. The 2012 reform sought to encourage the use of APAs and the validity of these APAs was extended and changed to be applicable to the year for which it is requested, the year before, and the following three years. ${ }^{92}$ Whether these changes to the APA regime are effective in enhancing the relationship between the tax administration and the taxpayers is not yet assessed, but the fact that the lack of trained personnel leads to possible breaches of the Chinese wall between the audit and APA teams remains as a barrier towards the effectiveness of this measure.

The South African tax authority lists as a key objective the development of an enhanced relationship between itself and other tax authorities, and with corporate taxpayers. In an attempt to enhance transparency as to the interpretation of the tax law, the tax authority publishes interpretation notes (which may be relied on by the taxpayer). Further general guidance is given in the form of guides and media releases, but these do not have the force of law. In addition, South Africa has introduced an advance tax ruling regime ${ }^{93}$ aiming to provide some certainty regarding a proposed transaction or scheme. However, the types of transactions for which these rulings may be sought severely restricts this regime. Despite these various forms of guidance, the legislation is frequently amended where the tax administration finds the outcome of tax cases unfavourable. Such a stance, while justifiable in some instances, does not provide certainty, clarity or reliability on tax rules.

Two mechanisms to enhance transparency and the relationship between tax authorities and taxpayers exist in Uruguay. A binding tax inquiry regime, laid down in Article 71 to 74 of the Tax Code, permits a taxpayer having a personal and direct interest to ask the tax administration for the application of legislation specified in the inquiry to an existing transaction. Alternatively, the taxpayer may make use of the advanced pricing regime (APAs) for transfer pricing issues (Article 44bis of the Income Tax on Economic Activities (IRAE)). ${ }^{94}$ An APA under this regime is up to three fiscal years, providing certainty and reliability on the ruling.

The Brazilian and the South African positions show that more instruments to give certainty to the taxpayer on the tax consequences of their transactions do not necessarily result in a better relationship between the tax administration and the taxpayer. Often the interpretation and position of the tax administration is not always available to the public i.e. other taxpayers than the ones involved in the ruling, creating an atmosphere of distrust between the taxpayers and the tax authorities and the perceptions of unfair tax practices. For most of these countries it is too early to establish whether these initiatives have been successful to tackle ATP and to enhance

\section{Notes}

91 Introductory note to the Law 1607 of 2012.

92 Art. 260 (10) Colombian Tax Code.

93 Ch. 7 (ss 75 to 90) of the Tax Administration Act (TAA) No. 28 of 2011.

94 The APA instrument was introduced by Decree 392/2009 (Art. 314 of Law 18996 granted legal status to the APA provisions), which states that the Uruguayan General Tax Bureau (GTB) may execute APAs with taxpayers, which must be signed before performing the transactions under analysis and that may not exceed the term of the three following fiscal years from which the APA was signed. The term will be applicable to financial years closing after the year in which this regime comes into force. Information available at International Transfer Pricing 2013/2014 PWC at 862. http://www.pwc.com/gx/en/international-transfer-pricing/assets/uruguay.pdf (accessed 31 Aug. 2017). 
more compliance by the companies engaged in tax planning arrangements.

\section{Conclusions AND RECOMMENDATIONS}

Following the comparative overview of the GAARs and enhanced relationships in the surveyed countries it is apparent that the surveyed countries need to not only exchange information but also enhance the standard of fiscal transparency, including availability, clarity, simplicity and reliability of the anti-avoidance rules and to improve the relationship between the taxpayers and the tax administration.

The measures taken by the selected countries are not currently consistent with this standard of fiscal transparency. The implementation of anti-avoidance measures is inconsistent and depends on the use and interpretation of anti-avoidance rules by the tax administration and judiciary. Furthermore, the application of the anti-avoidance rules to ATP is yet to be determined. Further detrimental to fiscal transparency and enhanced taxpayer-tax authority relationships is the example of Brazil where the tax administration has decided to use (without any legal basis) the business purpose doctrine. While mainly due to the lack of regulation (ordinary law) that is necessary for the implementation of the doctrine of sham/simulation in the Brazilian Tax Code, such application is damaging to the system, transparency and the tax authority's relationship with taxpayers. This position is exacerbated by contradictory decisions given by the Brazilian Administrative Council of Tax Appeals (Conselho Administrativo de Recursos Fiscais CARF) regarding tax treatment of investment made directly through controlled foreign companies.

The scope of application of the anti-avoidance rules of abuse of law and substance over form has been left to the tax administration in Colombia, rendering them unclear and failing in the standards of transparency. In Uruguay, the tax administration has applied the substance over form doctrine to tax avoidance, and also to tax evasion cases which is not in accordance with the intention of the legislator when introducing the substance over form doctrine. In South Africa, the tax administration only has the case law dealing with the old anti-avoidance rule even though a new anti-avoidance rule (section $80 \mathrm{~A}$ to $80 \mathrm{~L}$ Income Tax Act) was introduced in 2006.

From a tax policy perspective, it is submitted that the countries have struggled to find the right balance between the introduction of tax measures to tackle ATP and the introduction of transparent measures that provide clarity and reliability for the taxpayer.

While anti-avoidance rules and related instruments developed by the tax administration to interpret such rules exist, significant uncertainty remains for the taxpayer regarding the implementation and interpretation of GAARs by the tax administration. The lack of consistency in the application of anti-avoidance rules (Uruguay), reference to the case law pertaining to an old anti-avoidance rule for the application of a new anti-avoidance rule (South Africa), the broad scope of interpretation left to the tax administration (Colombia), the use of an anti-avoidance rule without legislative basis (Brazil) require clarification.

It follows from the research carried out in section 3 that there is always an element of subjectivity with respect to the application of a GAAR as its very nature requires analysis of the scheme on a case-by-case basis, but the broad implications of a classification in a category of avoidance should be transparent to the taxpayer (see section 3.2 above).

In this context, this article argues that individual states should clarify the application of the anti-avoidance rules, through further legislation or administrative regulation, as the current application has been demonstrated to be uncertain and unclear for taxpayers. Taxpayers cannot be expected to gain certainty based on the (subjective) application by the tax administration, and/or the interpretation by judges on a case by case basis. We submit that even though the GAAR should be drafted generally, the lack of rules to clarify the application of the GAAR may create uncertainty and/or court disputes.

Finally, from a tax policy perspective, it can be observed that in the surveyed countries, there is a hierarchical relationship between taxpayer and tax administration and a lack of disclosure of ATP arrangements. South Africa may be a counterpoint to this conclusion when considering its reportable arrangements legislation. Consultative (non-binding) tax rulings, whereby the taxpayer and the tax administration can discuss the tax treatment and the application of GAAR to specific tax arrangements, may be an avenue to provide greater certainty and clarity to the taxpayer - provided such rulings are consistent and transparent (i.e. disclosed in redacted form). However, such an approach rests on the successful development of an enhanced relationship based on mutual trust and legitimate expectations between the taxpayer and the tax administration.

\section{I Recommendations}

To achieve transparency in respect of ATP, anti-avoidance rules should be available to and clear for the tax administration to enforce consistently to provide the taxpayer boundaries in the application on which the taxpayer may rely. To achieve clarity in the application of the GAAR, it is recommended that mechanisms are put in place to enhance the relationship between the taxpayer and the tax administration. This can be partly achieved in offering consultative (non-binding) rulings through which the taxpayer can request the tax administration for its views of a specific transaction. The taxpayer should be able to disclose tax planning arrangements without fearing any risk of penalties upon disclosure. This consultative ruling should also allow the tax administration to assess in advance whether those arrangements would be considered as ATP or not. The tax administration should also be able to express the likelihood of the application of the GAAR to the disclosed / proposed 
transaction. Even though such rulings would not be binding, the taxpayer would be forewarned with respect to the tax authority view. Such advance knowledge may shape taxpayer behaviour to reduce tax planning perceived as aggressive.

Bentley supports such systems, stating that 'the proliferation of ruling regimes provides a significant source of assistance to taxpayers in the assessment process, particularly in relation to complex or uncertain areas of the tax law'. ${ }^{95}$ This recommendation does bear the caveat that an appropriate level of trust must be created between the tax authorities and the taxpayer, but such ruling may assist in this regard and, secondly, that the rulings issued should be published.

Another way to obtain more certainty is by means of horizontal supervision which is based on trust and transparency and where the tax authorities are prepared to respond to the taxpayer's need for certainty by signing an agreement between the tax administration and the taxpayer. This horizontal supervision requires from the taxpayer to be completely transparent and not to be engaged in ATP. As rightly stated by Gribnau, horizontal monitoring could contribute to taxpayers moving away from ATP towards tax risk management ${ }^{96}$ and certainty. ${ }^{97}$

In developing co-operative compliance to deal with ATP, the role that tax consultants could play should also be considered. Tax consultants could be used in a consultative capacity. Alternatively, or in addition, tax consultants could, in a trusting relationship, provide input to the tax administration of particularly ATP schemes. However, such engagement requires a nonadversarial and trusting relationship between the tax administration, tax consultant and, the taxpayer. It is submitted that the use of advanced tax rulings, horizontal monitoring, and disclosure requirements for all tax planning arrangements could help the tax administration monitor ATP. Furthermore, these instruments could provide taxpayers with greater transparency in terms of availability, clarity, and reliability on the tax consequences of their tax planning arrangements.

\section{Notes}

95 D. Bentley, The Rise of 'Soft Law' in Tax Administration - Good News for Taxpayers?, Vol. 33 (1) Asia-Pacific Tax Bull.(2008).

96 In order to address the tax risks the 2013 and 2016 OECD reports on Co-operative Compliance introduced tax control frameworks. See s. 5 supra. Co-operative compliance will be addressed in a forthcoming (2018) article in the framework of the DeSTaT project.

97 This is the case for instance in the Netherlands as argued by Gribnau For Gribnau, this change of attitude by the multinationals is mainly due to horizontal monitoring that means that, on 'the basis of trust and transparency, the tax authorities are prepared to respond to the multinationals' need for certainty'. See H. Gribnau, Soft Law and Taxation: The Case of the Netherlands, 3 Legisprudence 325 (2007). 